\title{
Comparison of laboratory methods in the diagnosis of urinary tract infection
}

\author{
B. I. DUERDEN AND A. MOYES
}

From the Department of Bacteriology, Edinburgh University Medical School, Teviot Place, Edinburgh EH8 $9 A G$

SYNOPSIS Three methods of semiquantitative culture and two techniques of microscopy were compared with a surface viable count for the detection of significant bacteriuria in one thousand midstream specimens of urine. The results obtained with the blotting-paper-strip method on MacConkey agar and with Uricult dip-slides correlated well with the results of the surface viable count, and both methods were suitable for routine use. The blotting-paper-strip method was preferred for laboratory use because of expense but dip-slides are useful for general practice and outpatient clinics. Semiquantitative culture by Microstix dip-strips gave less accurate results, and the nitrite test area detected only a small proportion of infected specimens. The microscopic examination of a Gram-stained film of the centrifuged deposit of urine specimens yielded more useful information and was more reproducible than examination of a wet film of the untreated urine.

The diagnosis of urinary tract infection relies principally upon the demonstration of significant bacteriuria (Kass, 1956; 1957) by quantitative culture of a midstream specimen of urine (MSSU), and this is the most common examination performed in the diagnostic laboratory. In the bacteriology laboratories of the Royal Infirmary, Edinburgh, MSSUs comprised $25 \%$ of the 121261 specimens submitted from the hospital and $60 \%$ of the 13936 specimens from general practitioners in 1974.

The standard methods for performing a total viable count by a pour plate technique or a surface viable count (Miles et al, 1938) are expensive of technician-time and materials and are impracticable for routine use. A number of simple semiquantitative methods have therefore been developed to discriminate between significant, doubtful, and not-significant viable counts. These include sampling the urine by a standard blotting-paper strip (Ryan et al, 1962) or a calibrated loop (McGeachie and Kennedy, 1963) to transfer aliquots to a suitable agar medium, and two commercially produced systems-Uricult (Orion Diagnostica, Helsinki, Finland) and Microstix (Ames Company, Slough, England). Uricult dip-slides have given reliable results in trials in general practice and hospital outpatient clinics (Guttman and Naylor, 1967; McDonald et al, 1972). Microstix, a more recent innovation, are plastic strips incorporating two areas of dehydrated culture medium for 'total'

Received for publication 15 October 1975 and 'Gram-negative' viable counts and an area containing nitrite reagents.

The examination of an MSSU also includes a microscopic examination. Pyuria does not necessarily correlate with significant bacteriuria (Kass, 1957; Rengarts, 1960) but may indicate an inflammatory process within the urinary tract. The presence of many squamous epithelial cells, lactobacilli, and occasionally monilia or Trichomonas vaginalis indicates vaginal contamination. Moreover, the observation of large numbers of bacteria indicates the need for primary antibiotic sensitivity tests.

This study was undertaken to determine the most suitable technique for the examination of large numbers of MSSUs in a busy diagnostic laboratory and to assess the place and relative merits of two commercial products.

\section{Material and Methods}

SPECIMENS

One thousand MSSUs were randomly taken from those sent to the laboratories from medical, surgical, urological, gynaecological, and obstetrical units, the surgical outpatient department, and general practitioners. The specimens were collected without vulval cleansing. They were held at $4^{\circ} \mathrm{C}$ and examined within 2 hours of receipt.

QUANTITATIVE CULTURE METHODS All incubation was at $37^{\circ} \mathrm{C}$ and results were read after 18 hours. 
TOTAL VIABLE COUNT

A surface viable count was made on MacConkey agar (Oxoid No. 2) and human-blood agar (5\% human blood in Oxoid Columbia Agar base) by a modification of the Miles and Misra method. A 100fold dilution of urine and three subsequent 10 -fold dilutions were made using a Finnpipette (Buckley Membranes Ltd, Amersham, England) with sterilized disposable tips to deliver $0.1 \mathrm{ml}$ into $9.9 \mathrm{ml}$ or $0.9 \mathrm{ml}$ of $20 \%$ nutrient broth in saline. Five $0.02 \mathrm{ml}$ drops of each dilution were delivered from a Finnpipette onto half a Petri dish of each medium. Colonies were counted in the areas of the five drops $(0 \cdot 1 \mathrm{ml})$ at the dilution giving 4-40 colonies per drop where possible.

\section{BLOTTING-PAPER-STRIP METHOD}

Two blotting-paper strips (Postlip, fibre-free) with a 'foot' measuring $12 \times 6 \mathrm{~mm}\left(\frac{1}{2} \times \frac{1}{4}\right.$ in) were dipped into each specimen and then held upright to absorb excess fluid. One was impressed on MacConkey agar and the other on $5 \%$ human-blood agar. The number of colonies in the area of the 'foot' was counted after incubation. The method had been previously calibrated in the laboratory: $<15$ colonies represented $<10^{4}$ organisms $/ \mathrm{ml} ; 15-20$ colonies represented $>10^{4}$ but $<10^{5}$ organisms $/ \mathrm{ml}$; and $>20$ colonies were obtained with $>10^{5}$ organisms $/ \mathrm{ml}$.

\section{URICULT}

The dip-slides with MacConkey agar on one side and nutrient agar on the other were used according to the manufacturer's instructions. The viable count was assessed by comparing the density of growth on each medium with the manufacturer's standard charts.

\section{MICROSTIX}

The strips were used according to the manufacturer's instructions. A strip was immersed in urine for 5 seconds and the nitrite test area was observed for 30 seconds for a pink colour produced by the reaction of nitrite with $p$-arsanilic acid and $\mathrm{N}$-(1-naphthyl)ethylene diamine. It was then inserted into its plastic pouch which was sealed after excess air had been expelled. After incubation the density of pink spots produced by bacterial reduction of triphenyltetrazolium in the media was compared with the manufacturer's standard colour blocks to assess the viable count on each medium.

\section{FALSE-POSITIVE AND FALSE-NEGATIVE RESULTS}

False-positive and false-negative results with the semiquantitative methods were determined by comparing (1) the results obtained with the blottingpaper-strip method on MacConkey agar, the Uricult MacConkey agar, and the Microstix 'Gram-negative' area with the surface viable count on MacConkey agar, and (2) the results obtained with the blottingpaper-strip method on blood agar, the Uricult nutrient agar, and the Microstix 'total' area with the surface viable count on blood agar.

\section{MICROSCOPIC EXAMINATION}

Each specimen was examined twice:

\section{(1) Direct Wet Film}

One drop of the well-mixed urine was placed on a microscope slide, a cover-slip was applied, and the film was viewed with the $\times 40$ objective lens under reduced illumination. The presence of pus cells, epithelial cells, and bacteria was recorded as follows: - or \pm for none or only occasional cells (the normal finding); + for $>10$ cells seen when scanning the film; and ++ for one or more cells in each field. The presence of red blood cells (RBC), monilia or $T$. vaginalis was noted.

\section{(2) Gram-stained Film of Deposit}

Specimens were centrifuged at $3000 \mathrm{rev} / \mathrm{min}$ for 5 minutes and one loopful of the deposit was used to prepare a Gram-stained film which was viewed with the oil-immersion objective lens. The presence of pus cells, epithelial cells, and bacteria was recorded as follows: - or \pm for none or only occasional cells; + for frequent clumps of cells; and ++ for sheets of cells. The presence of RBC and monilia was noted.

All films were examined independently by both authors.

\section{Results}

\section{SURFACE VIABLE COUNT}

The results of the surface viable counts on blood agar and MacConkey agar are shown in table Ia. Nine specimens where the results obtained with the two media differed gave significant growth on blood agar but a doubtful result (1) or no growth (8) on MacConkey agar; five were infected with haemolytic streptococci, one each with an enterococcus, Staphylococcus albus, and Escherichia coli, and one was a monilial infection in a diabetic patient. Three specimens gave significant growth on MacConkey agar and doubtful results on blood agar, and three gave doubtful results on blood agar and no growth on MacConkey agar.

The bacteria isolated from the specimens that gave significant growth are shown in table II. The 24 mixed infections included 18 where a Gram-negative bacillus and a Gram-positive coccus were isolated; five contained two distinct Gram-negative bacilli and one contained a staphylococcus and a streptococcus. 


\begin{tabular}{|c|c|c|c|c|c|c|c|c|c|c|c|c|c|}
\hline \multirow[t]{2}{*}{ Result $^{2}$} & & \multicolumn{3}{|c|}{$\begin{array}{l}\text { (a) } \\
\text { Surface Viable Count }\end{array}$} & \multicolumn{3}{|c|}{$\begin{array}{l}\text { (b) } \\
\text { Blotting-paper-strip }\end{array}$} & \multicolumn{3}{|l|}{$\begin{array}{l}\text { (c) } \\
\text { Uricult }\end{array}$} & \multicolumn{3}{|l|}{$\begin{array}{l}\text { (d) } \\
\text { Microstix }\end{array}$} \\
\hline & & $B A$ & $M A$ & $\begin{array}{l}\text { Both } \\
\text { Media }\end{array}$ & $B A$ & $M A$ & $\begin{array}{l}\text { Both } \\
\text { Media }\end{array}$ & $N A$ & $M A$ & $\begin{array}{l}\text { Both } \\
\text { Media }\end{array}$ & $\begin{array}{l}\text { Total } \\
\text { Area }\end{array}$ & $\begin{array}{l}\text { Gram- } \\
\text { negative } \\
\text { Area }\end{array}$ & $\begin{array}{l}\text { Both } \\
\text { Areas }\end{array}$ \\
\hline $\begin{array}{l}\text { S } \\
\text { D } \\
\text { NS }\end{array}$ & & $\begin{array}{r}210 \\
68 \\
722\end{array}$ & $\begin{array}{r}204 \\
63 \\
733\end{array}$ & $\begin{array}{r}201 \\
62 \\
722\end{array}$ & $\begin{array}{r}211 \\
43 \\
746\end{array}$ & $\begin{array}{r}193 \\
36 \\
771\end{array}$ & $\begin{array}{r}190 \\
23 \\
743\end{array}$ & $\begin{array}{r}191 \\
73 \\
736\end{array}$ & $\begin{array}{r}198 \\
62 \\
740\end{array}$ & $\begin{array}{r}186 \\
54 \\
731\end{array}$ & $\begin{array}{r}162 \\
92 \\
746\end{array}$ & $\begin{array}{r}156 \\
68 \\
766\end{array}$ & $\begin{array}{r}145 \\
63 \\
737\end{array}$ \\
\hline Total & & 1000 & 1000 & 985 & 1000 & 1000 & 956 & 1000 & 1000 & 971 & 1000 & 1000 & 945 \\
\hline $\begin{array}{l}\text { False } \\
\text { positive } \\
\text { results }\end{array}$ & $\begin{array}{l}\text { No. } \\
\text { Rate }\end{array}$ & $\begin{array}{l}\cdots \\
\cdots\end{array}$ & $\begin{array}{l}\cdots \\
\cdots\end{array}$ & $\begin{array}{l}\cdots \\
\cdots\end{array}$ & $\begin{array}{l}11 \\
5.2 \%\end{array}$ & $\begin{array}{l}7 \\
3.6 \%\end{array}$ & $\begin{array}{l}5 \\
2.6 \%\end{array}$ & $\begin{array}{l}4 \\
2 \cdot 1 \%\end{array}$ & $\begin{array}{l}7 \\
3.5 \%\end{array}$ & $\begin{array}{l}1 \\
0.5 \%\end{array}$ & $\begin{array}{l}11 \\
6.8 \%\end{array}$ & $\begin{array}{l}15 \\
9.6 \%\end{array}$ & $\begin{array}{l}9 \\
6.2 \%\end{array}$ \\
\hline $\begin{array}{l}\text { False } \\
\text { negative } \\
\text { results }\end{array}$ & $\begin{array}{l}\text { No. } \\
\text { Rate }\end{array}$ & $\begin{array}{l}\cdots \\
\ldots\end{array}$ & $\begin{array}{l}\cdots \\
\ldots\end{array}$ & $\begin{array}{l}\cdots \\
\cdots\end{array}$ & $\begin{array}{l}10 \\
1.4 \%\end{array}$ & $\begin{array}{l}18 \\
2.4 \%\end{array}$ & $\begin{array}{l}6 \\
0.8 \%\end{array}$ & $\begin{array}{l}24 \\
3.3 \%\end{array}$ & $\begin{array}{l}13 \\
1 \cdot 8 \%\end{array}$ & $\begin{array}{l}11 \\
1.5 \%\end{array}$ & $\begin{array}{l}59 \\
7.9 \%\end{array}$ & $\begin{array}{l}63 \\
8.2 \%\end{array}$ & $\begin{array}{l}45 \\
6.1 \%\end{array}$ \\
\hline
\end{tabular}

Table I Results of viable bacterial counts on midstream specimens of urine

${ }^{1} \mathrm{~S}=$ significant result $\left(>10^{5}\right.$ organisms $\left./ \mathrm{ml}\right) ; \mathrm{D}=$ doubtful result $\left(>10^{4}\right.$ but $<10^{5}$ organisms $\left./ \mathrm{ml}\right) ; \mathrm{NS}=\mathrm{not}$ significant $\left(<10^{4}\right.$ organisms $\left./ \mathrm{ml}\right) ;$ BA = blood azar; MA $=$ MacConkey agar; NA = nutrient agar

\begin{tabular}{lc}
\hline Bacterial Species & Number \\
\hline E. coli (typical) & 100 \\
E. coli (atypical) & 17 \\
Proteus mirabilis & 26 \\
Staph. albus & 21 \\
Enterococcus & 7 \\
P. aeruginosa & 4 \\
K. aerogenes & 3 \\
B-haemolytic streptococcus & 5 \\
Staph. aureus & 2 \\
a-haemolytic streptococcus & 3 \\
Candida albicans & 1 \\
Mixed & 24 \\
Total & 213 \\
\hline
\end{tabular}

Table II Bacteria isolated from specimens that gave significant growth

Similar bacteria were isolated from the 65 specimens that gave doubtful results.

\section{BLOTTING-PAPER-STRIP METHOD}

The results obtained with the blotting-paper-strip method are shown in table Ib. Twenty specimens where different results were obtained with the two media gave a doubtful result on one medium (18 on blood agar) and no growth on the other. Twentyfour specimens gave significant growth on one medium ( 21 on blood agar) but a doubtful result (13) or no growth on the other. Gram-positive cocci were isolated from 13 specimens that gave significant growth only on blood agar and one was the monilial infection already noted.

All the false-positive results were obtained from specimens that gave doubtful results by the surface viable count. Seven of the false-negative results on blood agar and 13 on MacConkey agar gave doubtful results and the remaining eight gave no growth.
The false-negative group for MacConkey agar does not include the eight specimens that contained significant numbers of Gram-positive cocci (7) or monilia (1) that failed to grow on any MacConkey agar plate. E. coli (4), an enterococcus, and a mixture of the two were isolated from specimens that gave false-negative results on both media. Specimens that gave false-negative results only on MacConkey agar contained Gram-negative bacilli (6), Gram-positive cocci (5), and mixed bacteria (1). Those that gave false-negative results only on blood agar contained E. coli (2), Staph. albus, and a $\beta$-haemolytic streptococcus.

Nineteen of the 62 specimens that gave doubtful results on both media in the surface viable count gave doubtful results on both media with the blottingpaper-strip method; five gave significant growth on both media, 19 gave no growth on either medium, and 19 gave mixed results.

\section{URICULT DIP-SLIDES}

The results obtained with Uricult dip-slides are shown in table Ic. Twelve specimens where different $N$ results were obtained with the two media gave a doubtful result on one medium ( 7 on nutrient agar) 0 and no growth on the other. Fifteen specimens gave $\omega$ significant growth on one medium (12 on MacConkey agar) but a doubtful result on the other, and two specimens, both containing $a$-haemolytic strep- $\mathbb{\Phi}$ tococci, gave significant growth on nutrient agar but ? no growth on MacConkey agar. Ten Gram-negative bacilli and two Gram-positive cocci were isolated from the specimens that gave significant growth on MacConkey agar and a doubtful result on nutrient $\stackrel{\mathbb{Q}}{\varrho}$ agar.

All the false-positive results were obtained from 8 specimens that gave doubtful results by the surface 
viable count. The specimens that gave false-negative results on both media contained Gram-negative bacilli (6), enterococci (2), and mixed growth (1). Those that gave false-negative results only on nutrient agar contained Gram-negative bacilli (6), Gram-positive cocci (6), and monilia (1). One E. coli and one Staph. albus were isolated from the specimens that gave false-negative results only on MacConkey agar.

Thirty-nine of the 62 specimens that gave doubtful results on both media in the surface viable count gave doubtful results on both Uricult media; nine gave no growth on either medium; only one gave significant growth on both media, and the other 13 gave a mixture of results.

\section{MICROSTIX DIP-STRIPS}

The viable counts estimated using the Microstix dipstrips are shown in table Id. Twenty-seven specimens where different results were obtained on the two media gave a doubtful result on one area (24 on the 'total' area) and no growth on the other. Twentyeight specimens gave significant growth on one area and a doubtful result (7) or no growth on the other. The 11 specimens that gave significant growth only on the 'Gram-negative' area contained Gram-negative bacilli (8) or mixed bacteria (2), but no bacteria were isolated from one specimen by conventional methods. Fourteen specimens that gave significant growth only on the 'total' area contained Gram-positive cocci, two contained $E$. coli, and one a mixture of bacteria.

Eleven specimens that gave false-positive results gave doubtful results in the surface viable count but six gave no growth. Twenty-two specimens that gave false-negative results on both areas gave doubtful results on one (9) or both (13) areas, and 23 gave no growth on either area. Twenty-three false-negative results were obtained from specimens infected with Gram-negative bacilli, 16 with Gram-positive cocci, and six with mixtures of bacteria.

Twenty of the 62 specimens that gave doubtful results on both media in the surface viable count gave doubtful results on both Microstix areas; 18 gave no growth on either area; six gave significant growth on both areas; and 18 specimens gave different results on the two areas.

\section{Microstix Nitrite Test}

The results of the nitrite test incorporated in the Microstix dip-strips are shown in table III. The test was positive in only 46 of the 213 infected specimens.

\section{MICROSCOPIC FINDINGS}

(1) Pus Cells

An increased number of pus cells was seen in 154 $(72 \%)$ wet films and in $161(75 \%)$ Gram-stained films

\begin{tabular}{llc}
\hline Result & & Number \\
\hline Negative & & 953 \\
Positive & & 47 \\
Total & & 1000 \\
& Nalse positive results & \\
& Rate & 1 \\
False negative results & No. & $2 \cdot 1 \%$ \\
& Rate & 167 \\
& & $17.5 \%$ \\
\hline
\end{tabular}

Table III Results of Microstix nitrite test

from specimens that gave significant growth, although the increase was small in 25 wet films and in 31 Gram-stained films. Pyuria was also found in 179 $(25 \%)$ wet films and in $210(29 \%)$ Gram-stained films from specimens that gave no growth, and was heavy in 87 wet films and 105 Gram-stained films. Only half of the specimens with heavy pyuria and $20 \%$ with mild pyuria were infected.

\section{(2) Bacteria}

Bacteria were seen in $187(88 \%)$ wet films from specimens that gave significant growth and in 37 $(57 \%)$ that gave doubtful results. They were also seen in $174(24 \%)$ specimens that gave no growth and were in large numbers in 78 of them. The specimens that gave significant growth when bacteria were not seen included a greater proportion that contained Gram-positive cocci than was found in all specimens that gave significant growth. Bacteria were seen in the Gram-stained films from all except two specimens that gave significant growth, and bacteria with the appropriate morphology were noted in 138 $(88 \%)$ specimens containing Gram-negative bacilli and in $33(87 \%)$ specimens containing Gram-positive cocci in significant numbers; 'mixed organisms' were recorded in 22 specimens that gave a significant growth of one species. Both Gram-negative bacilli and Gram-positive cocci were noted in 15 of the 18 specimens from mixed infections. Gram-negative bacilli were noted in $22(34 \%)$ specimens that gave doubtful results but in only $24(3.3 \%)$ specimens that gave no growth. Gram-positive cocci were seen in 16 $(23 \%)$ specimens that gave doubtful results but in only $33(4.6 \%)$ specimens that gave no growth.

Gram-positive bacilli were noted in $15-20 \%$ of all Gram-stained films.

\section{(3) Other Elements}

Squamous epithelial cells, RBC, and monilia were seen in approximately equal proportions of specimens that gave significant growth and no growth, and in a slightly higher proportion of those that gave doubtful results. RBC were seen more frequently in the wet film, but epithelial cells and monilia were more readily detected in the Gram-stained films. 
INTER-OBSERVER DIFFERENCES

The two observers recorded different findings for pus cells, bacteria, or epithelial cells in $87(8.7 \%)$ wet films and $42(4.2 \%)$ Gram-stained films. In the above analysis the higher grading was used.

The assessment of pus cells differed in 36 wet films, of which 16 differed by two grades (' - or \pm ' and ' ++ '); different grades were recorded in 19 Gramstained films but only five differed by two grades. A different bacterial content was recorded in 61 wet films of which 30 differed by two grades; different grades were recorded in 12 Gram-stained films and the interpretation differed in only six films. The assessment of epithelial cells differed in 22 wet films, of which eight differed by two grades, and in $30 \mathrm{Gram}$ stained films of which 13 differed by two grades.

\section{Discussion}

This study was undertaken to compare several methods of quantitative culture and microscopic examination of MSSUs for routine use in a busy hospital laboratory. The basic requirements are a simple and accurate method of quantitative culture and a microscopic examination that enables a rapid and consistent assessment of cells and bacteria.

The surface viable count is unsuitable for routine use but provided an essential reference standard with which the other methods could be compared. The variety of bacterial species isolated in significant numbers reflects the varied population of patients in a large hospital with specialized urological, renal, gynaecological, and obstetric units. The methods used in a laboratory that receives specimens from such units must detect all the potentially pathogenic species.

The results obtained with the blotting-paper-strip method on MacConkey agar confirm previous reports (Leigh and Williams, 1964) that this method is suitable for routine use. The false-positive and false-negative rates were low, and most false-negative results were recorded as doubtful results that required another specimen. No bacterial species gave consistently false results and most were isolated on MacConkey agar. The Gram-positive cocci and the monilia that were detected only on blood agar probably do not justify the inclusion of culture on blood agar in a routine examination. Gram-positive cocci that fail to grow on MacConkey agar can be detected by plating a loopful of the urine deposit on blood agar when Gram-positive cocci are seen by microscopy. All these strains were isolated from hospital inpatients, and a second specimen was readily obtained when necessary for semiquantitative culture on blood agar.

Uricult dip-slides also gave satisfactory results.
The false-positive and false-negative rates were low and no bacterial species gave consistently false results. The results on MacConkey agar were more reliable than those on nutrient agar, which gave more false-negative results and did not detect the Grampositive cocci that failed to grow on MacConkey agar. Uricult dip-slides are too expensive for routine use in the laboratory where the equally reliable and cheaper blotting-paper-strip method can be used. They are, however, useful in general practice (Guttman and Naylor, 1967) and in busy outpatient departments and antenatal clinics (McDonald et al, 1972). Microstix were tested as potential alternatives to the dip-slides, but the results of semiquantitative culture were less satisfactory and the nitrite test detected only $22 \%$ of all infected specimens. This test is even less sensitive than a laboratory nitrite test (Sleigh, 1965; Craig et al, 1973).

The microscopic examination was principally used to detect potentially significant bacteriuria so that a primary antibiotic sensitivity test could be set up and a full report issued within 18 hours of receiving the specimen. The relationship between pyuria and significant bacteriuria is debatable (Kass, 1957; Rengarts, 1960; McGeachie and Kennedy, 1963). Both methods of microscopy gave similar assessments of pyuria which was absent in $25 \%$ of specimens that gave significant growth and present in $25 \%$ that gave no growth. Either method gave adequate results for a qualitative report of the presence or absence of pus cells as an index of inflammation within the urinary tract. The observation of squamous epithelial cells provided a useful index of contamination of the specimen whichever method was used.

The major difference between the two methods was in the assessment of bacterial content. The presence of Gram-negative bacilli or Gram-positive cocci in the Gram-stained film of the centrifuged deposit was the most reliable index of significant bacteriuria. Bacteria were seen in the wet films from the same proportion of specimens that gave significant growth, but also in $24 \%$ of specimens that gave no growth. A Gram-stained film was then needed from these specimens to determine the morphology of the bacteria. Moreover, the accurate examination of a Gram-stained film is a quicker and more reliable technical operation with fewer observer errors than the examination of a wet film, and this is important in a busy laboratory. The only observation for which the wet film was more reliable was the recording of $\mathrm{RBCs}$, and this is of little importance in routine specimens.

As a result, we have adopted the following procedure for the routine processing of MSSUs: (1) A blotting-paper-strip culture is made on MacConkey agar; (2) the urine is centrifuged at $3000 \mathrm{rev} / \mathrm{min}$ for 
5 minutes and one loopful of the deposit is used to prepare a Gram-stained film that is immediately examined; (3) if potentially significant bacteriuria is seen, one loopful of the deposit is used to seed a primary antibiotic sensitivity plate on which appropriate discs are placed; (4) if Gram-positive cocci predominate in the film, another loopful of the deposit is used to seed a sector (1) of a blood-agar plate to detect those strains that do not grow on MacConkey agar. The results are read after incubation for 18 hours at $37^{\circ} \mathrm{C}$.

We should like to thank Professor B. P. Marmion, Dr R. R. Gillies, and Mr I. Samuel for support and encouragement, and the Ames Company, Division of Miles Laboratories Limited, Stoke Court, Stoke Poges, Slough, England, for providing the Microstix.

\section{References}

Craig, W. A., Kunin, C. M., and deGroot, J. (1973). Evalua- tion of new urinary tract infection screening devices. Appl. Microbiol., 26, 196-201.

Guttman, D. and Naylor, G. R. E. (1967). Dip-slide: An aid to quantitative urine culture in general practice. Brit. med. J., 3, 343-345.

Kass, E. H. (1956). Asymptomatic infections of the urinary tract. Trans. Ass. Amer. Phycns., 69, 56-63.

Kass, E. H. (1957). Bacteriuria in the diagnosis of infections of the urinary tract. Arch. intern. Med., 100, 709-714.

Leigh, D. A. and Williams, J. D. (1964). Method for the detection of significant bacteriuria in large groups of patients. J. clin. Path., 17, 498-503.

McDonald, P. J., Furness, E. T., and Beasley, N. V. (1972). Dip-slide diagnosis of urinary tract infection. Med.J. Aust., 1, 20-23.

McGeachie, J. and Kennedy, A. C. (1963). Simplified quantitative methods for bacteriuria and pyuria. J. clin. Path., 16, 32-38.

Miles, A. A., Misra, S. S., and Irwin, J. O. (1938). The estimation of the bactericidal power of the blood. J. Hyg. (Lond.), 38, 732-749.

Rengarts, R. T. (1960). Asymptomatic bacilluria in sixtyeight diabetic patients. Amer. J. med. Sci., 239, 159-164.

Ryan, W. L., Hoody, S., and Luby, R. (1962). A simple quantitative test for bacteriuria. J. Urol., 88, 838-840.

Sleigh, J. D. (1965). Detection cf bacteriuria by a modification of the nitrite test. Brit. med.J., 1, 765-767. 